\title{
Changes in foraging as a response to predation risk in two gobiid fish species, Pomatoschistus minutus and Gobius niger
}

\author{
Carin Magnhagen \\ Department of Zoology, Uppsala University, Box 561, S-751 22 Uppsala, Sweden
}

\begin{abstract}
The influence of predation risk and hunger level on the foraging rate and swimming activity in the sand goby Pomatoschistus minutus and the black goby Gobius niger was tested in aquarium experiments. The fish were given a choice of 2 habitats, viz. vegetation without food, and open sediment with natural prey density. Both species had a lower food consumption in the presence of predators than without predators, but starved fish had a higher consumption rate than fed fish both in the presence and in the absence of predators. Starved fish thus took higher risks of being eaten than did fed fish. $P$. minutus decreased their swimming activity in the presence of predators, which may have caused the lower food intake. However, $G$. niger did not change their activity with predator presence. Habitat choice must also be of importance for the foraging rate in gobies. G. niger were mostly found in the vegetation, which is their natural habitat. $P$. minutus to a greater extent inhabit open areas in the field and therefore might gain more from decreasing their activity than seeking cover at high predation risk.
\end{abstract}

\section{INTRODUCTION}

Many studies have shown that the risk of being eaten by a predator may influence the foraging of an animal (Milinski \& Heller 1978, Krebs 1980, Sih 1980, Dill 1983, Lima et al. 1985, Metcalfe et al. 1987. Magnhagen 1988). There are often trade-offs to be made between different behaviours (Sih 1980, Dill \& Fraser 1984, Lima et al. 1985, Milinski 1986), and it is important to examine the interactions between different demands such as the need for predator avoidance, feeding and mating, in order to understand the foraging patterns of an animal (Sih 1987). One goal for a forager should be to maximize its probability of survival (Mangel \& Clark 1986, McNamara \& Houston 1986), and different behaviours could be profitable in different situations depending for example on predation risk and hunger level. There are several ways to avoid predators. To decrease the risk of detection an animal can either use refuges (Mittelbach 1981, Cerri \& Fraser 1983, Werner et al. 1983, Power 1984, 1987, Schlosser 1987 ) or reduce its activity (Dill 1983, Dill \& Fraser 1984, Godin 1986, Sih 1986, Giles 1987, Prejs 1987). Both these strategies, however, can be costly in terms of lost opportunities to feed. A hungry animal may have to take higher risk of being eaten, in order to get the food it requires, than a less hungry one (Mangel \& Clark 1986, McNamara \& Houston 1986). According to the foraging models developed by Mangel \& Clark (1986) and McNamara \& Houston (1986) the 'metabolic state' of an animal (e.g. energy level or gut contents) is the factor that decides the choice of actions made by the animal, since the state determines the probability of survival given a certain behaviour.

The sand goby Pomatoschistus minutus (Pallas) and the black goby Gobius niger L. (Gobiidae) are marine benthic fish species occurring in great numbers in shallow soft-bottom areas along the Swedish coast. $G$. niger has a strong preference for vegetated habitats, while $P$. minutus is found both in vegetation and in open areas (Magnhagen \& Wiederholm 1982, Wiederholm 1987). Both species feed on invertebrate prey, mostly crustaceans. Pihl (1982) reported that cod Gadus morhua L. preys upon gobies, especially in the autumn, and other potential predators in these areas include sculpins Myoxocephalus scorpius (L.) and eels Anguilla anguilla (L.).

In this study I examine the foraging behaviour in these 2 gobiid fishes, more specifically the effect of predation risk and hunger level on foraging. Aquarium 
experiments were performed to look at food intake, habitat choice and activity, in the presence and absence of a predator. I wanted to test whether the foraging rates were affected by predation risk, and if so, what mechanisms could explain the changes. Furthermore, would hunger level affect the response to predators as predicted by Mangel \& Clark (1986) and McNamara \& Houston (1986), i.e. would a starved fish take higher risks to be eaten in order to get food than a fish with a higher energy reserve?

\section{METHODS}

The study was carried out in July and August 1987 at Klubbans Biological Station, Fiskebäckskil, on the west coast of Sweden $\left(58^{\circ} 15^{\circ} \mathrm{N}, 11^{\circ} 28^{\prime} \mathrm{E}\right)$. Pomatoschistus minutus were caught with a hand-trawl at depths $\leq 1 \mathrm{~m}$ in a shallow bay in the vicinity of the laboratory, and Gobius niger were caught in an eelgrass (Zostera marina L.) meadow at depths of 1 to $2 \mathrm{~m}$ using a beam trawl. The fish were taken to the laboratory and kept in storage tanks. They were either starved for $1 \mathrm{wk}$ or fed twice a day with commercial salmon pellets, mussels and live invertebrates, in order to obtain fish with 2 hunger levels.

Feeding experiment. To study food intake and habitat choice in the presence and absence of predators, 4 fish tanks offering the choice between 2 habitats, one with food and the other with protection from predators, were used. The volume of the fish tanks was ca $1800 \mathrm{l}$, with a bottom area of $2.3 \mathrm{~m}^{2}$. The bottom substrate in half of each tank consisted of sediment taken from the same area as Pomatoschistus minutus, scooped up in such a way as to minimize disturbance of the infauna (mostly Corophium volutator (Pallas) and Nereis diversicolor $O$. F. Müller) and to provide natural prey density. In the other half the bottom was covered with sand from the beach which contained no prey organisms. On the sand were placed plastic aquatic plants, imitating eelgrass, to provide cover. The water was continuously renewed, with temperatures around $15^{\circ} \mathrm{C}$.

Twelve gobies were put in each tank at 23:00 h. Observations on habitat choice started at 08:00 h the following morning. Once every hour, the number of fish seen in the 2 habitats was registered. At 19:00 h the fish were removed, anaesthetized in MS222, and frozen. Their stomachs were later analyzed, number of prey counted and their stomach contents dried for $48 \mathrm{~h}$ at $60^{\circ} \mathrm{C}$ and weighed.

In 2 of the tanks the gobies used were starved for $1 \mathrm{wk}$ before the experiment started, while in the other 2 they had previously been fed twice a day. In 2 of the tanks there was 1 cod (body length $\mathrm{ca} 20 \mathrm{~cm}$ ) to provide predation risk (the cod actually ate a few gobies during each run). The experimental setup thus created 4 different treatments: starved fish with and without predator, and fed fish with and without predator. The experiments were repeated 5 times each for Pomatoschistus minutus and Gobius niger. Mean body length was $55.1 \pm 9.4 \mathrm{~mm} \quad(N=182)$ for $P$. minutus and $56.8 \pm 10.5 \mathrm{~mm}(N=200)$ for $G$. niger.

Activity experiment. The swimming activities of Pomatoschistus minutus and Gobius niger, in the presence and absence of predators, was measured using photo-cells registering number of passages across an infra-red beam. The aquaria used were octogonal (diam. $=60 \mathrm{~cm}$ ) with double walls, $10 \mathrm{~cm}$ apart, creating 2 separate sections, an outer and an inner (Fig. 1).

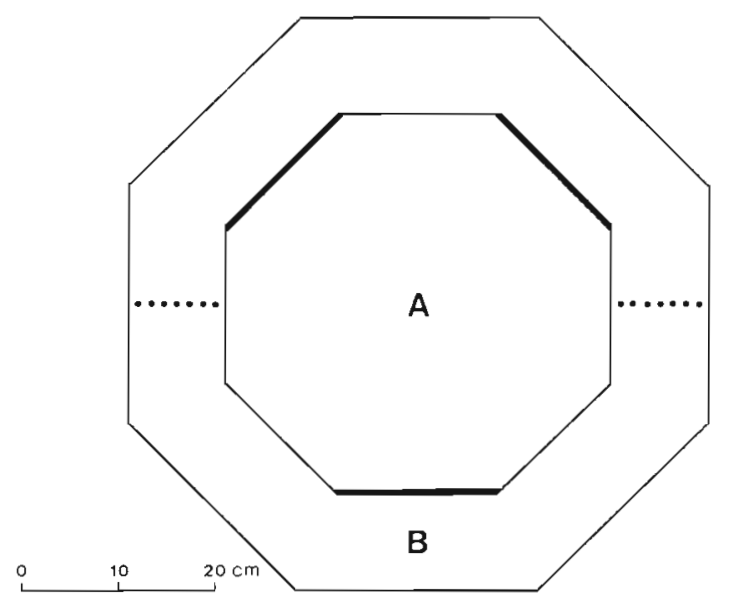

Fig. 1. Design of activity aquarium, shown from above. A: predator chamber; $B$ : goby chamber; $\cdots \cdot$ location of infrared beams; $\longrightarrow$ : masonite screens

The outer section $\left(16 \mathrm{dm}^{2}\right)$ was used for the tested fish. The bottom substrate consisted of muddy sand and the amphipod Corophium volutator was provided as prey (ca 150 per aquarium). The inner section $\left(12 \mathrm{dm}^{2}\right.$ ) was used for the predator in 2 of the 3 aquaria used. The predator could clearly be seen by the gobies in the outer section and vice versa. The third aquarium served as a control without predator. Three of the 8 walls between the sections were screened to give the gobies a possibility of hiding from the predator. Water flow in both sections was continuous and water temperature about $15^{\circ} \mathrm{C}$. Water depth was $20 \mathrm{~cm}$. The light

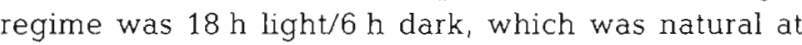
this time of the year.

Each experiment was run for $48 \mathrm{~h}$. Three gobies were put in each aquarium. One cod was used in the inner section of each 'predation risk' aquarium to simulate predation risk during first $24 \mathrm{~h}$. The cod were then removed to check that the presence of the predator actually caused the difference in activity between the 
'predation risk' situation and the control. In one of the 'predation risk' aquaria, the gobies had been starved for ca 1 wk, while in the other fish that previously had been continuously fed were used. In the control aquarium the fish were previously fed. The experiments were repeated 5 times with Pomatoschistus minutus and 6 times with Gobius niger. Each individual fish was used only once in the experiments.

\section{RESULTS}

\section{Feeding experiments}

The observations on habitat choice were pooled for each treatment within each replicate. The proportions of fish found in the open habitat were arcsin $V_{x}$ transformed and the influence of predator presence, hunger level and species was tested in a 3-way ANOVA. Predator presence and species were found to have a significant influence on habitat choice $\left(F_{(1,24)}=\right.$ $23.5, p<0.001 ; F_{(1,24)}=45.6, p<0.001$, respectively). In the presence of predators more fish were found in the open habitat than in the absence of predators

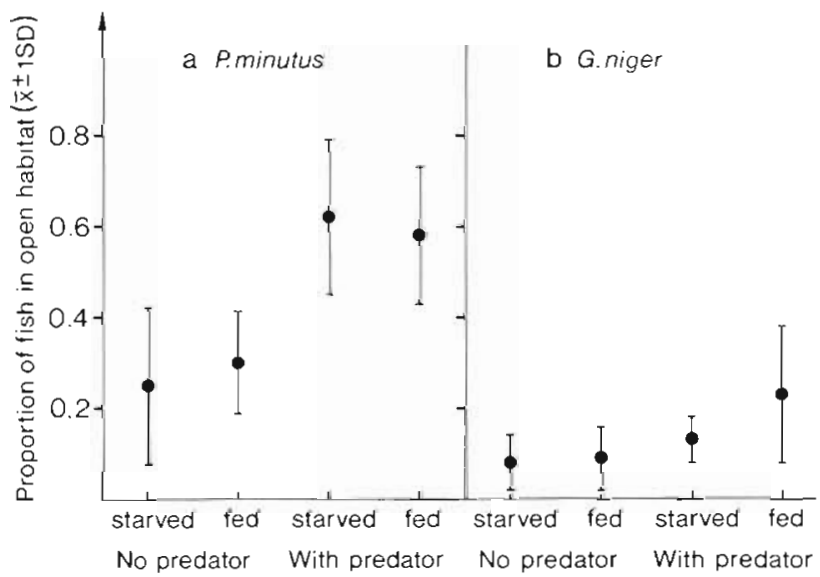

Fig. 2. (a) Pomatoschistus minutus and (b) Gobius niger. Proportion of fish found in the open habitat in the foraging rate experiment. Data points show the means ( $\pm 1 \mathrm{SD}$ ) from 4 experiments for both fish species

(Fig. 2). More Pomatoschistus minutus than Gobius niger were found in the open. Usually only a low proportion of the fish were in the open habitat; only $P$. minutus in the presence of predators occupied the open area to more than $50 \%$.

Food intake was calculated as the mean dry weight of the stomach contents from the fish in each replicate treatment. A 3-way ANOVA on the $\log (x+1)$ transformed data tested the influence of predator presence, hunger level and species. All 3 factors had a significant influence on the food intake $\left[F_{(1.31)}=9.0, p<0.01\right.$ (predator presence); $F_{(1,31)}=12.6, p<0.01$ (hunger level); $F_{(1,31)}=6.7, p<0.05$ (species). Starved fish had a higher consumption than fed fish, and Pomatoschistus minutus ate more than Gobius niger (Fig. 3). Fish at the same hunger level had a higher food intake in the absence of predators.

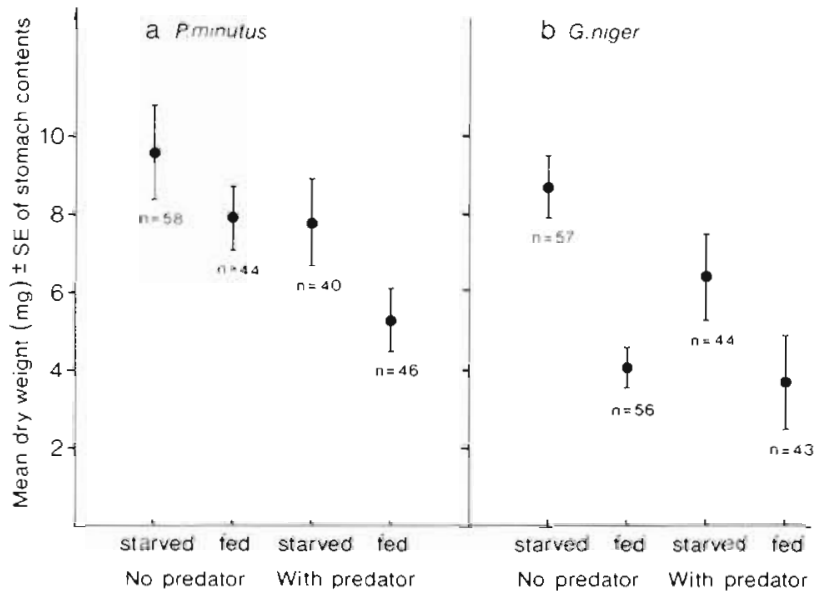

Fig. 3. (a) Pomatoschistus minutus and (b) Gobius niger. Mean dry weight (mg) \pm SE of stomach contents from the fish in the foraging rate experiments

\section{Activity experiments}

The swimming activity is expressed as the number of times per hour the fish passed either of the 2 photocells in each aquarium (Fig. 4). The means for the light periods and the dark periods were used when testing the effect of predator presence, hunger and light on the activity (3-way ANOVA, Table 1).

In the Pomatoschistus minutus experiments a higher activity was found during the first $24 \mathrm{~h}$ in the aquarium without predator compared to the others (Table 1; Fig. 4). On the second day, when the predators were removed, however, the fish in the 'predation risk' aquaria increased their activity and there were no differences between the 2 aquaria during Day 2 (Fig. 4). During the dark period the activity was lower during both Day 1 and Day 2 (Table 1).

In the Gobius niger experiments light influenced the activity only during Day 1 (Table 1). This was mainly due to the high activity during the first hours the fish spent in the aquarium (when disregarding the data from the first $4 \mathrm{~h}$, there was no significant difference between day and night). During Day 2 the starved fish had a significantly lower activity than the fed fish. There were no differences in activity aquaria with or without predator. 

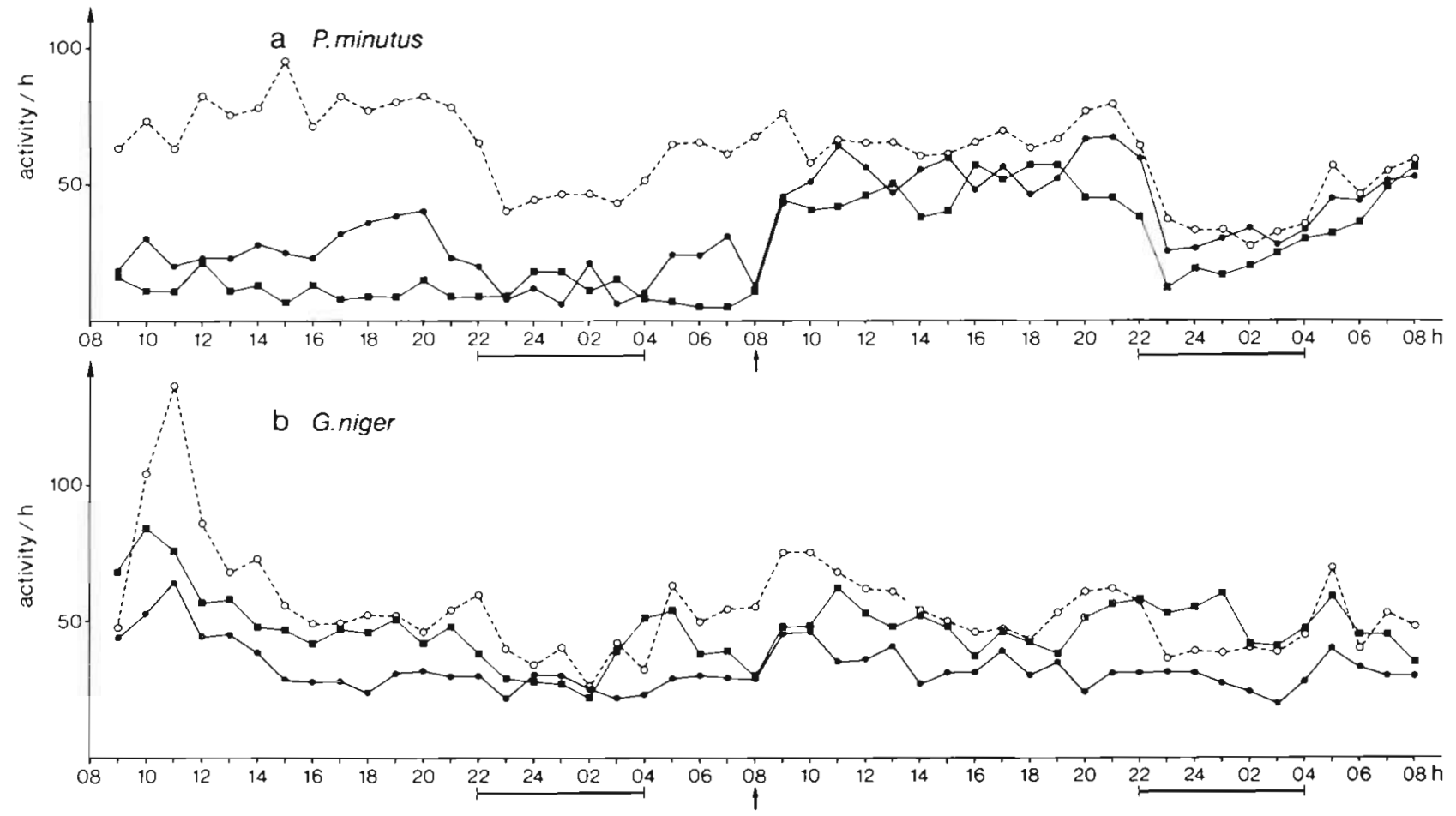

Fig. 4. (a) Pomatoschistus minutus and (b) Gobius niger. Activity measured as number of passages per hour by 3 fish through an

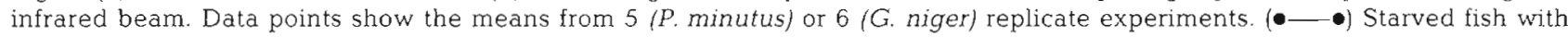
predator present; $(-\infty)$ fed fish with predator present; $\left(\_\right)$fed fish without predator; bars: dark periods; arrows: removal of predators

Table 1. Pomatoschistus minutus and Gobius niger. Three-way ANOVA on the mean activity per hour measured as number of passages by 3 fish through an infra-red beam. P: predator presence; $H$ : hunger level; L: light condition. On Day 2 the predators were removed, and $\mathrm{P}$ is then comparing the aquaria that previously had a predator present with the control aquarium

\begin{tabular}{|c|c|c|c|c|}
\hline \multirow[t]{2}{*}{ Source } & \multicolumn{2}{|c|}{ Day 1} & \multicolumn{2}{|c|}{ Day 2} \\
\hline & $F_{(1,24)}$ & $P$ & $F_{(1,24)}$ & $p$ \\
\hline \multicolumn{5}{|c|}{ Pomatoschistus minutus } \\
\hline P & 29.4 & $<0.001$ & 1.5 & NS \\
\hline $\mathrm{H}$ & 0.5 & NS & 0.9 & NS \\
\hline \multirow[t]{2}{*}{ L } & 6.4 & $<0.05$ & 13.5 & $<0.05$ \\
\hline & $F_{(2,30)}$ & $p$ & $F_{(1,30)}$ & $p$ \\
\hline \multicolumn{5}{|c|}{ Gobius niger } \\
\hline $\mathrm{P}$ & 1.7 & NS & 0.0 & NS \\
\hline $\mathrm{H}$ & 2.4 & NS & 7.0 & $<0.05$ \\
\hline L & 6.7 & $<0.05$ & 2.7 & NS \\
\hline
\end{tabular}

\section{DISCUSSION}

Both Pomatoschistus minutus and Gobius niger changed their foraging as a response to predation risk. Furthermore, the response differed depending on hunger level. However, the higher food intake in the absence of predators was not due to increased utilization of the habitat with the higher prey density as would be expected. In the presence of a predator both species, but especially P. minutus, were found more commonly in the open area than otherwise, even if most of $G$. niger still remained in the vegetation. This can depend on the location of the predator. The cod spent ca $70 \%$ of their time in the vegetation, and thus the choice for the gobies was between seeking cover or maximizing their distance from the predator. For $P$. minutus, which is not as strongly associated with vegetation as $G$. niger, the structure of the sediment may be more important than vegetation. At least to the human eye, $P$. minutus were actually more cryptic on the open sediment, which was more heterogeneous, with holes from burrowing animals etc., than on the smooth sand in the other area. Furthermore, $P$. minutus has the ability to burrow which also suggests that type of substrate may be more important than presence of cover

The lower average food intake in Gobius niger compared to Pomatoschistus minutus was probably due to the fact that the former occupied the vegetation to a higher extent. Thus, in $G$. niger which usually lives in vegetation, cover seems more important than type of substrate, and the differences between the 2 species 
found in the experiments probably reflect the differences in their natural habitats. Obviously, in my experiments the division of the tanks into 2 habitats was of minor importance for the results, but the difference between treatments in food intake depended instead on differences in foraging activity.

An animal is more visible when moving than when stationary, hence decreasing activity would lower the risk of being detected by a visually searching predator as well as decreasing prey encounter rate (Sih 1987). Banded killifish Fundulus diaphanus (LeSueur) reduced the rate of feeding attempts in the presence of a predator (Godin 1986). Prejs (1987) found a decrease in feeding activity in small tropical stream fishes in the presence of gape-limited predators compared with predator-free areas. Similarly, small crayfish Orconectes propinquus (Girard) reduced their activity and chose substrates offering protection as a response to predation risk (Stein \& Magnusson 1976). It is likely that a lower swimming activity in the presence of predators, as shown in the activity experiments for Pomatoschistus minutus, will lead to lower food consumption. This should also apply to Gobius niger since they too consumed less food in the presence of a predator. However, in this species there was no decrease in activity in the experiments. Earlier studies on activity in $G$. niger showed that their activity was lower in the presence of cover (Hesthagen 1976). In my experiments no vegetation or any other kind of cover were provided, and therefore the activity might have been higher than it would otherwise have been, and maybe higher than in the foraging rate experiments, where vegetation was present.

Starved fish had a higher food intake than fed ones, both in the presence and in the absence of predators. Obviously, they were taking higher risks in order to get food than did the fed fish. This probably reflects a trade-off between energy requirements and the risk of being eaten by a predator. Situations like this are likely to arise in habitats and at seasons with low food availability. Hungry animals have previously been found to be less responsive to predators, e.g. fish (Milinski \& Heller 1978, Dill \& Fraser 1984, Magnhagen 1988), insects (Bailey 1986, Wellborn \& Robinson 1987), and birds (Krebs 1980). The tendency to take higher risks at higher hunger levels is a behaviour that is predicted by the foraging models developed by Mangels \& Clark (1986) and McNamara \& Houston (1986). The animal is expected to always choose the behaviour that maximizes the probability of survival. By looking at the 'metabolic state' of the animal it is possible to predict what risks it should take, its habitat choice, activity level, etc. The changes in foraging behaviour made by Pomatoschistus minutus and Gobius niger as a response to predation risk and hunger level thus agree with predictions made by Mangel \& Clark (1986) and McNamara \& Houston (1986). However, choice of activity made by an animal may also be influenced by demands other than energy intake and predator avoidance, such as reproduction and territorial defence.

Acknowledgements. I thank Anders Berghund, Bodil Enoksson, Anders Pape Møller, Gunilla Rosenkvist, Ingrid Svensson and Staffan Ulfstrand for help and valuable comments on the manuscript. The work was supported by a grant from the Swedish Natural Science Research Council.

\section{LITERATURE CITED}

Bailey, P. C. E. (1986). The effect of predation risk on the predatory behaviour of a sit-and-wait predator, Ranatra dispar (Heteroptera:Nepidae), the water stick insect. J. Ethol. 4: 17-25

Cerri, R. D., Fraser, D. F. (1983). Predation and risk in foraging minnows: balancing conflicting demands. Am. Nat. 121. 552-561

Dill, L. M. (1983). Adaptive flexibility in the foraging behaviour of fishes. Can. J. Fish. Aquat. Sci. 40: 398-408

Dill, L. M., Fraser, A. H. G. (1984). Risk of predation and the feeding behaviour of juvenile coho salmon (Oncorhynchus kisutch). Behav. Ecol. Sociobiol. 16: 65-71

Giles, N. (1987). Predation risk and reduced foraging activity in fish: experiments with parasitized and non-parasitized three-spined sticklebacks, Gasterosteus aculeatus L. J. Fish Biol. 31. 37-44

Godin, J.-G. J. (1986). Risk of predation and foraging behaviour in shoaling banded killifish (Fundulus diaphanus). Can. J. Zool. 64: 1675-1678

Hesthagen, I. H. (1976). Locomotory activity of the black goby, Gobius niger L. (Pisces, Gobiidae), under artificial light conditions, including a false dawn and dusk. Sarsia 62 : 9-18

Krebs, J. R. (1980). Optimal foraging, predation risk and territory defense. Ardea 68:83-90

Lima, S. L.. Valone, T. J., Caraco, T (1985). Foraging efficiency-predation-risk trade-off in the grey squirrel. Anim. Behav. 33: 155-165

Magnhagen, C. (1988). Predation risk and foraging in juvenile pink (Oncorhynchus gorbuscha) and chum (O. keta) salmon. Can. J. Fish. Aquat. Sci. 45: 592-596

Magnhagen, C., Wiederholm, A.-M. (1982). Habitat and food preferences of Pomatoschistus minutus and P. microps (Gobiidae) when alone and together: an experimental study. Oikos 39: 152-156

Mangel, M., Clark, C. W. (1986). Towards a unified foraging theory. Ecology 67: 1127-1138

McNamara, J. M., Houston, A. I. (1986). The common currency for behavioral decisions. Am. Nat. 127: 358-378

Metcalfe, N. B., Huntingford, F. A., Thorpe, J. E. (1987). The influence of predation risk on the feeding motivation and foraging strategy of juvenile Atlantic salmon. Anim. Behav. 35: 901-911

Milinski, M. (1986). Constraints placed by predators on feeding behaviour In: Pitcher, T J. (ed.) The behaviour of teleost fishes. Croom Helm Ltd. London, Sydney, p. 236-252

Milinski, M., Heller, R. (1978). Influence of a predator on the optimal foraging behaviour of sticklebacks (Gasterosteus aculeatus L.). Nature, Lond 275: 642-644 
Mittelbach, G. G. (1981). Foraging efficiency and body size: a study of optimal diet and habitat use by bluegills. Ecology 62: $1370-1386$

Pihl, L. (1982). Food intake of young cod and flounder in a shallow bay on the Swedish west coast. Neth. J. Sea Res. 15: $419-432$

Power, M. E. (1984). Depth distribution of armored catfish: predator-induced resource avoidance? Ecology 65: $523-528$

Power, M. E. (1987). Predator avoidance by grazing fishes in temperate and tropical streams: importance of stream depth and prey size. In: Kerfoot, W C., Sih, A. (eds.) Predation: direct and indirect impacts on aquatic communities. University Press of New England, Hanover, London, p. 333-351

Prejs, A. (1987). Risk of predation and feeding rate in tropical freshwater fishes: field evidence. Oecologia (Berl.) 72: 259-262

Schlosser, I. J. (1987). The role of predation in age- and size-related habitat use by stream fishes. Ecology 68: $651-659$
Sih, A. (1980). Optimal behavior can foragers balance two conflicting demands? Science 210: 1041-1042

Sih, A. (1986). Antipredator responses and the perception of danger by mosquito larvae. Ecology $67 \cdot 434-441$

Sih, A. (1987). Predators and prey lifestyles: an evolutionary and ecological overview. In: Kerfoot, W. C., Sih, A. (eds.) Predation: direct and indirect impacts on aquatic communities. University Press of New England, Hanover, London, p. 203-224

Stein, R. A., Magnusson, J. J. (1976). Behavioural response of crayfish to a fish predator. Ecology 57:751-761

Wellborn, G. A., Robinson, J. V. (1987). Microhabitat selection as an antipredator strategy in the aquatic insect Pachydiplax longipennis Burmeister (Odonata: Libellulidae). Oecologia (Berl.) 71: 185-189

Werner, E. E., Mittelbach, G. G., Hall, D. J., Gilliam, J. F. (1983). Experimental test of optimal habitat use in fish: the role of relative habitat profitability. Ecology 64: 1525-1539

Wiederholm, A.-M. (1987). Habitat selection and interactions between three marine fish species (Gobiidae). Oikos 48: $28-32$

This article was submitted to the editor; it was accepted for printing on August 25, 1988 